\title{
A review of histomorphometric analysis techniques for assessing implant-soft tissue interface
}

Type: Journal Article

\begin{abstract}
:
The success of dental implant treatment depends on the healing of both hard and soft tissues. While osseointegration provides initial success, the biological seal of the periimplant soft tissue is crucial for maintaining the long term success of implants. Most studies of the biological seal of peri-implant tissues are based on animal or monolayer cell culture models. To understand the mechanisms of soft tissue attachment and the factors affecting the integrity of the soft tissue around the implants, it is essential to obtain good quality histological sections for microscopic examination. The nature of the specimens, however, which consist of both metal implant and soft peri-implant tissues, poses difficulties in preparing the specimens for histomorphometric analysis of the implant-soft tissue interface. We review various methods that have been used for the implant-tissue interface investigation with particular focus on the soft tissue. The different methods are classified and the advantages and limitations of the different techniques are highlighted.
\end{abstract}

\begin{tabular}{|c|l|}
\hline Author & Chai, W. L. ; Moharamzadeh, K. ; Brook, I. M. ; VanNoort, R. \\
\hline Source & Biotechnic \& Histochemistry \\
\hline ISSN & $1052-0295$ \\
\hline DOI & $10.3109 / 10520291003707916$ \\
\hline Volume (Issue) & $86(4)$ \\
\hline Page & $242-254$ \\
\hline Year & 2011 \\
\hline
\end{tabular}

Keyword:

Dental implants, Histomorphometric analysis, Interface, Soft tissue, titanium, animal, confocal microscopy, human, immunohistochemistry, methodology, pathology, review, scanning electron microscopy, soft tissue injury, surface property, tooth implantation, wound healing, Animals, Humans, Microscopy, Confocal, Microscopy, Electron,, Scanning, Soft Tissue Injuries, Surface Properties, Animalia

Please Cite As:

W. L. Chai, K. Moharamzadeh, I. M. Brook, and R. VanNoort, 'A Review of Histomorphometric Analysis Techniques for Assessing Implant-Soft Tissue Interface', Biotechnic \& Histochemistry, 86 (2011), 242-54. 
URL:

- http://apps.webofknowledge.com >> search via web of science accession no: 000292779100004

- http://informahealthcare.com/doi/abs/10.3109/10520291003707916

- http://www.ncbi.nlm.nih.gov/pubmed/20392135

- http://www.ingentaconnect.com/content/apl/bah/2011/00000086/00000004/art00 $\underline{004}$

- http://eprints.um.edu.my/1946/

- http://www.scopus.com/inward/record.url?eid=2-s2.079960461238\&partnerlD $=40 \& \mathrm{md} 5=5908664 \mathrm{e} 251 \mathrm{~d} 0474 \mathrm{~d} 79 \mathrm{f} 69 \mathrm{f} 8 \mathrm{~d} 8 \mathrm{e} 8173 \mathrm{e}$ 